\title{
İnovasyon Ekosistemi Oluşturulması Bağlamında Firmaların İşbirliği Algısı: Tıbbi Medikal Sektöründe Bir Uygulama*
}

\begin{abstract}
Mustafa Kemal Topcu ${ }^{1}$
ÖZ: Son dönem politikalar toplumsal refahın artırılması amacıyla özel sektör odaklı Ar-Ge ve inovasyon üzerine yoğunlaşmaktadır. Böylelikle, sanayi kesimindeki kalite ve verimlilik artışı sağlanarak, kalkınma planında ve vizyon belgelerinde yer aldı̆̆ı gibi ithalat bağımlılı̆̆ından kurtularak teknoloji ihraç edebilen bir Türkiye söz konusu olabilecektir. Bu hedefin gerçekleştirilebilmesi için ihtiyaç duyulacak beşeri sermayenin yetiştirilmesi görevini de üniversiteler üstlenmektedir. Bu üçlü yapının etkili bir şekilde kullanılabilmesi için inovasyon ekosistemlerinin oluşturulmasl gerekmektedir. İnovasyon ekosisteminin ana unsurlarl ise teknoloji işbirliği ve inovasyon networkleridir. Bu nedenle ekosistemin başat aktörlerinden sanayinin işbirliğine açık olması önemlidir. Bu doğrultuda yapılan bu çalışmada, firmaların işbirliği kapasitesinin belirlenmesi için hazırlanan soru formunun geçerlik ve güvenirlik analizleri yapılmıştır. Keşfedici faktör analizi sonucunda mikro seviyede firmalar arası ikili işbirliği ve makro seviyede işbirliği ağları arasında işbirliği olmak üzere iki faktörlü bir yapı ortaya çıkmıştır. Güvenirlik analizi sonuçlarl da kabul edilebilir düzeyde elde edilen soru formunun kullanılabilir olduğunu göstermiştir. Ayrıca çalışmada bölgesel inovasyon ekosistemi oluşturulması çerçevesinde bazı bulgu ve sonuçlar paylaşılmış ve önerilerde bulunulmuştur.
\end{abstract}

Anahtar Kelimeler: İnovasyon, Ar-Ge, Ekosistem, Üniversite-Sanayi Işsirliği, İşbirliğ

JEL Kodu: $M 11,032$

\section{Cooperation Perceptions of Firms for Creating Innovation Ecosystem: An Application in Medical Equipment Sector}

\begin{abstract}
Recent policies focus on private sector based research and development and innovation in order to increase public welfare. Towards this end, Turkey may export technology and know-how provided that quality and productivity in industry are acquired while fleeing from import dependency as mentioned in development plans and vision documents. Universities assume responsibility for providing human capital required to realize this aim. In order to make efficient use of these three bodies, creating innovation ecosystems is a must. Main elements of innovation ecosystem are technological cooperations and innovation networks. Therefore, it is required that industry, as one of main actors, be open to cooperate. To this end, validity and reliability of prepared questionnaire to identify cooperation capacities of firms are made in this study. As a result of exploratory factor analysis, two factors are explored; dyadic cooperation among firms at micro level and cooperation among networks at macro level, relatively. It is also contended that questionnaire may be used once reliability analysis results are acceptable. In addition, some findings and results are shared regarding innovation ecosystem concept and some recommendations are made.
\end{abstract}

Keywords: Innovation, $R \& D$, Ecosystem, University-Industry Collaboration, Cooperation JEL Codes: $M 11, O 32$

Geliş Tarihi / Received: 09/09/2018

Kabul Tarihi / Accepted: 08/10/2018

\footnotetext{
* Bu makale Ankara Kalkınma Ajansı'nın İleri Teknolojilerde İhracat Odaklı Kalkınma Mali Destek Programı kapsamında yürütülen Teknoloji Ara Birimi Projesi kapsamında hazırlanmıştır. İçerik ile ilgili tek sorumluluk yazarına aittir ve T.C. Ankara Kalkınma Ajansı'nın görüşlerini yansıtmaz.

${ }^{1}$ Dr., ST Strateji ve Teknoloji Geliştirme Ltd. Şti., mktopcu@ ststrateji.com, orcid.org/0000-0002-3298-1283
} 


\section{Giriş}

Türkiye pazar büyüklügü açısından ilk 20 ekonomi arasından yer alırken inovasyon bakımından arzu edilen seviyeyi yakalayamamaktadır (Ersöz, 2009a, 2009b; Özbek ve Atik, 2013). Keza, Dünya Ekonomik Forumu 2017-2018 küresel rekabet raporuna göre Türkiye 137 ülke içerisinde 53. sırada yer almaktadır. Küresel rekabet endeksinin alt kırılımlarından inovasyonda ise 69. sıraya kadar gerilemiştir. Benzer şekilde, küresel yenilikçilik endeksinde de 126 ülke arasında 50. sırada yer almaktadır (Cornell University, INSEAD ve WIPO, 2018). 2018 yılı AB İnovasyon Skorkartında da Türkiye, Bulgaristan ve Letonya ile birlikte son siralarda gelmektedir. Büyüme oranı AB'den fazla olan Türkiye'nin inovasyon performans1 2010-2017 yıllar1 arasında neredeyse yatay bir seyir izleyerek \%45'den ancak \%60'a çıkabilmiştir (Innovation Union Scoreboard, 2018).

$\mathrm{Bu}$ durumun arkasındaki nedenler incelendiğinde, KOBİ'lerin Ar-Ge harcamalarındaki payının 2013 yılı itibariyle \%16,9 olduğu ve bu değerin yalnızca \%14.4'ünün yatırıma dönüşebildiği görülmektedir (KOBİ Strateji ve Eylem Planı, 2015: 14). Diğer yandan Ankara için Ankara Ticaret Odası tarafindan 2015 yılında yapılan bir durum analizi çalışmasında ticaret sektörüne yönelik ortaya çıkan iyileştirmeye açık yönler arasında; Ankara' da rekabet gücünü artıracak olan kurumlar arasında ve sanayi kuruluşları arasında yaşanan bilgi ve koordinasyon eksikliği, ulusal ve bölgesel işbirliği faaliyetlerinin azlığ 1 , KOBI'lerin proje ve işbirliği kültürünün eksik olması ve akademisyenlerin iletişim ağlarında etkin olamaması yer almaktadır. Ekonominin \%99,5'ini oluşturan KOBİ'lerin bölgeler arası eşitsizliğin giderilmesindeki ve toplumsal refahın artırılmasındaki rolü ile birlikte bölgesel aktörler arasındaki işbirliği eksikliği göz önüne alındığında, Türkiye'nin 2023 vizyonunda yer alan dişa bağımlılıktan kurtulmak ve teknoloji ihraç edebilen bir ülke olmak hedeflerinden ne kadar uzak kaldığ 1 anlaşılabilir. Hedeflere ancak yenilikçi yöntemlerle ve kurumlar arası işbirliklerinin artırılmasıyla yaklaşılabilecektir. Çünkü teknolojik yenilik yaratma yeteneği firmaları uluslararası arenaya taşımakta ve sürdürülebilir rekabet avantajı elde edilmesini sağlamaktadır. Solow (1987) büyüme ve verimliliğin esas kaynağını teknolojik yenilik olarak kabul etmektedir. Nitekim inovasyon toplumsal refahın ve kalkınmanın anahtarı olarak görülmektedir (Elçi ve Karataylı, 2008: 2).

Bu bilinçle kamu politikalarında özel sektör odaklı Ar-Ge ve inovasyona öncelik verilmektedir. Ancak özel sektörün, özellikle KOBİ'lerin, kendi çabaları ve özkaynakları ile teknolojik yenilik yaratabilmesi ve katma değerli ürünler üretebilmesi zor görünmektedir. Bu sebeple devlet kolaylaştırıcı bir rol üstlenerek uygulamaları rahatlatıcı politikalar belirlemeye ve çeşitli fonlarla finansmana erişimini basitleştirmeye çalışmaktadır. Diğer taraftan, sanayi kesiminin taleplerinin devlet ve üniversite tarafından tam olarak anlaşılamadığ $\breve{g}_{1}$ bilinmektedir (Hancıoğlu ve Atay, 2018: 74). Bu nedenle, sanayi kesiminin 
gereksinimlerini net olarak tanımlanmasını sağlayacak oluşumlara ihtiyaç bulunmaktadır.

Özellikle sanayi ve ticaret kesimini temsil eden kuruluşların; firmaların inovasyon kapasitelerinin artırılmasına destek ve yönlendirme yapacak, ulusal politika ve belgelerde öncelik almaya başlayan üniversite-sanayi işbirliğinin artmasına katkı sağlayacak ve beşeri sermayenin geliştirilmesine öncülük edebilecek yapılara kavuşması gerekmektedir. Böylelikle, bölgesel yenilik sistemine kazandırılacak işlerlik ile katma değerli ürünler yaratılarak Türkiye'nin vizyonuna daha fazla katk1 verilebilecektir. Bu doğrultuda yapılan bu çalışmada ilk olarak inovasyon ekosistemi bağlamında kavramsal bir inceleme yapılmıştır. Müteakiben şirketlerin yenilikçilik kaynağı olarak işbirliklerine ilişkin algılarını ölçmek üzere geliştirilen ölçme aracına ve bulgulara yer verilmiştir. Sonuç kısmında ise ölçme aracı tartışılarak, beklentiler ortaya konmuş ve bazı öneriler sunulmuştur.

\section{Kavramsal Çerçeve}

Onuncu Kalkınma Planında, "Yenilikçi Üretim, İstikrarlı Yüksek Büyüme" ekseninde, güçlü bir imalat sanayine duyulan ihtiyaca vurgu yapılarak, imalat sanayinin toplam katma değer içerisindeki payının artırılması amacı ortaya konmuştur. $\mathrm{Bu}$ amacin gerçekleştirilebilmesi için kamu tarafindan öncelikle yapılacaklar içerisinde; etkin işleyen bir Ulusal Yenilik Sisteminin oluşturulması ve sistem içindeki aktörler arasındaki işbirliğinin desteklenmesi, özel kesimin ArGe kapasitesinin ve Ar-Ge'ye olan talebinin artırılması, araştırmacı insan gücü açığının giderilmesi ve yerli teknolojik yeteneklerin geliştirilmesi ve ürüne dönüştürülmesi amaçlanmıştır (DPT, 2010: 6).

Ulusal Yenilik Sistemlerini destekleyen politikalar; sanayi ve girişim politikası, yüksek eğitim politikası, bilim ve teknoloji politikası ve bölgesel politika olmak üzere dört kategoride ele alınmaktadır (OECD, 2008: 56). Sanayi ve girişim politikası özel sektör, özellikle KOBİ'ler, açısından teknolojinin benimsenmesi ve rekabet öncesi işbirliğinin desteklenmesini hedeflerken, yüksek eğitim politikası kurumlarda uzmanlaşmaya gidilip sanayi kesiminin ihtiyaç duyduğu beşeri sermayenin yetiştirilmesine odaklanmaktadır. Bilim ve teknoloji politikası ise belli bir ağ yapıda işbirliğine dayalı araştırmaların finanse edilmesini sağlamaktadır. Son olarak, bölgesel politikanın da yerel aktörlere ve kaynaklara dayalı rekabetçi bölgeler oluşturulmasını hedeflediği ifade edilebilir. Politikaların tam anlamıyla uygulanabilmesi ve hedeflere ulaşılabilmesi için paydaşlarla yakın işbirliğinin sağlanması özel önem taşımaktadır. Nitekim yenilik ekosistemlerinin iki ana unsuru teknoloji işbirliği ve inovasyon networkleridir (Cornell University, INSEAD ve WIPO, 2018: 14). Zira inovasyon için kritik becerilerin içerisinde diş paydaşlar dahil tüm aktörlerle işbirliği yapabilmek ön sıralarda yer almaktadır (Elçi ve Karatayl1, 2008: 17). Özellikle diğer firmalarla işbirliği yapabilmek ve araştırma kurumları ve üniversitelerle bağlantılı çalışabilmek inovasyona etki eden önemli faktörlerin içerisinde ön plana çıkmaktadır (Keizer ve diğ., 2002; Romero ve Martínez-Román, 2012: 179). 
$\mathrm{Bu}$ bağlamda, inovasyon ekosistemi yenilikçiliği etkileyen tüm kuruluşların kullandığı bir iletişim ağı olarak tarif edilebilir (Afzal, 2014: 507). Diğer bir ifade ile inovasyon ekosistemi; toplumsal kalkınma ve refahının anahtarı konumundaki inovasyonu geliştirmek için bir araya gelen kamu ve özel girişimcileri, araştırma kurumları, üniversiteler ve politika yapıcı ve düzenleyicilerin arasındaki işbirliğidir (Skiltere ve Jesilevska, 2013: 212). Ulusal inovasyon ekosistemlerinin esasında yenilikçiliğin kaynağı olan ya da yayılımını sağlayan aktörler arasındaki işbirliğini kavrayabilmek vardır (Hancıoğlu ve Atay, 2018: 55). Buradan hareketle bölgesel yenilik sistemleri; üniversite, sanayi ve devlet olmak üzere üç temel bileşen üzerine kurulmuştur. Klasik anlayışta lineer bir ilişki benimsenirken yakın zamana kadar paydașlar arasındaki karşılıklı ilişkiye vurgu yapan bir model kullanılmıştır. Günümüzde ise devlet-üniversite-sanayi işbirliği Şekil 1'de yer alan üçlü sarmal model ile karakterize edilmektedir (Etzkowitz ve Leydesdorff, 2000).

Şekil 1: Devlet-Üniversite-Sanayi İşbirliği Modeli

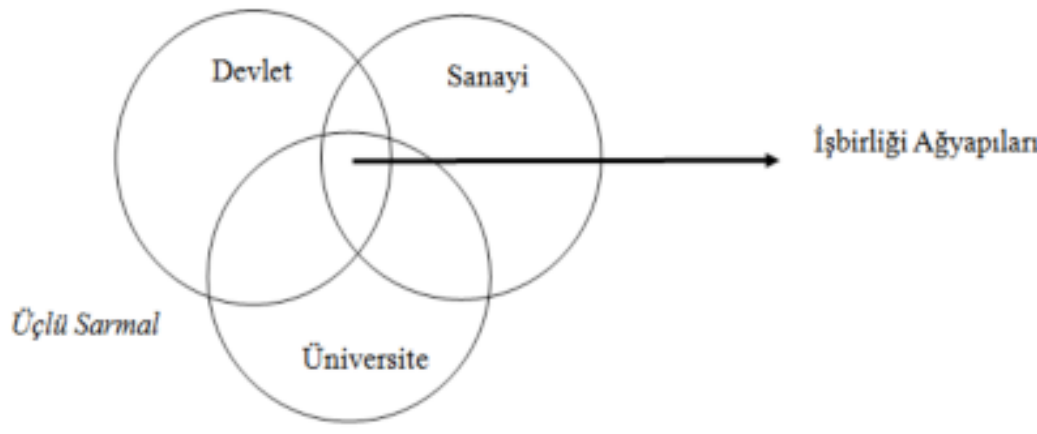

Kaynak: Etzkowitz ve Leydesdorff, 2000: 1111.

İşbirliği ile ortak çözümler üretilerek, taraflar açısından büyük kazanımlar elde edilebilecektir. Hem üniversite hem de sanayi kamu fonlarından daha fazla yararlanabilecektir. Sanayi açısından üretim süreçlerinde yapılacak iyileştirmelerle verimlilik ve kalite sağlanabilirken, üniversitelerde girişimcilik ön plana çıkabilecektir. Ayrıca, üniversiteler bilgi birikimini Ulusal ve Bölgesel İnovasyon Sistemlerine girdi olarak sunarken, küresel rekabet edebilir firmalar için beşeri sermayeyi de yetiştirmektedir. Kamu ise toplamda toplumsal refahın artırılmasında etkin bir araç kullanmış olacaktır. Bununla birlikte kamu, düzenleyici ve denetleyici bir rol üstlenmektedir. Sistem yaklaşımında devletin düzenleyici rolü; yenilik ve girişimcilik için uygun ortamın sağlanması, kümeleşmenin teşvik edilmesi ve yenilikçi ağların desteklenmesi gibi çeşitli tedbirleri kapsamaktadır (Dökmen, 2012: 148). Böylelikle, işbirlikleri ve ağlar yenilikçiliğin kaynağı haline gelebilir ve teknoloji transferi ve yayılımı gerçekleşebilir (Cornell University, INSEAD ve WIPO, 2018: 14). Bu doğrultuda Türkiye'de de KOBİ'lerin sanayi-sanayi ve üniversite-sanayi işbirliğinin 
geliştirilmesi stratejik hedef olarak benimsenmiştir (KOBİ Strateji ve Eylem Planı, 2015: 15). Ancak şirketlerin sadece işbirliğini geliştirmesi yeniliğin kaynağına ulaşmasını sağlayamayacaktır; bu nedenle, sosyal sermayesini güçlendirerek geniş bir networke de sahip olması önemlidir. Nitekim AB 2020 strateji belgesinde de nitelikli işgücü ile birlikte firmaların sosyal sermayesinin güçlendirilmesi için işbirlikleri ön plana çıkmıştır (Soylu, 2011: 117).

$\mathrm{Bu}$ amaçları gerçekleştirebilmek için, üniversitelerdeki araştırma ve teknoloji geliştirme yetenekleri konusundaki bilgileri sanayiye taşıyacak, buna karşıllk, sanayinin teknolojiye ilişkin ihtiyaçlarını da üniversiteye taşıyıp çözüm arayacak; her iki tarafın da dilini konuşabilen arayüzlere ihtiyaç bulunmaktadır (Göker, 2012). Bu arayüzleri; teknoloji transfer ofisleri, kuluçkalıklar, teknoloji transfer merkezleri ve Üniversite-Sanayi Ortak Araştırma Merkezleri olarak sıralamak mümkündür (Kiper, 2010).

$\mathrm{Bu}$ arayüzlerle birlikte KOSGEB ve TÜBİTAK gibi bazı kamu kurum ve kuruluşlar, ortak eğitim programları ve kümelenmeler de işbirliğini geliştirmek için çalışmalar yapmaktadır. Arayüzlerin temel görevlerinden birisi de oluşturulacak ekosistemler içerisinde yenilik sürecindeki bütün aktörlerin işbirliği içerisinde hareket etmelerine hizmet etmektir. Nitekim Yardımcı ve Müftüoğlu (2014: 2) tarafından da belirtildiği gibi bu arayüzler inovasyona ilişkin sorunlara çözüm üretilmesinde kritik bir role sahiptir. Ancak tarafların farklı odak alanlarına sahip olması işbirliğinin yaratılmasını mümkün kılan ortamın oluşmasını uzun erimli bir hale getirmektedir. Üniversite bilginin yayılmasını öncelerken sanayi ticari bilgi gizliliği ve rekabet anlayışı nedeniyle bilgi paylaşımına sıcak bakmamaktadır (Kiper, 2010: 47). Diğer taraftan özellikle gelişmekte olan ülkelerde arayüzlerin yeterli sayıda olmaması sistematik sorunlara yol açmaktadır (Tuncel, 2014: 50). Bu nedenlerle taraflar arasındaki işbirliğini geliştirmek için de yenilikten yararlanarak farklı yaklaşımları benimsemek fayda yaratabilir. Buradan hareketle bu çalışmada bölgesel inovasyon ekosistemini oluşturan ana unsurlarda oluşturulabilecek arayüzlerde firmaların işbirliği kapasitesini belirlemek için kullanılabilecek bir soru formu geliştirilmiştir. Bir sonraki kısımda soru formuna ilişkin bilgiler yer almaktadır.

\section{Yöntem}

\section{1. Ölçme Aracı}

Firmaların işbirliği kapasitesinin belirlenmesi için karma yöntem kullanılmıştır. Nitel yöntem olarak katılımcı firmalarla mülakat, nicel yöntem olarak anket uygulaması yapılmıştır. Bu maksatla hazırlanan soru formu mülakat yöntemi kullanılarak doldurulmuş ve kayıt altına alınmıştır. Görüşmeye başlamadan önce firmaya gizlilik taahhütnamesi sunulmuştur. Soru formu beş bölümden oluşmaktadır. İlk bölümde firmaya ve görüşülen kişiye ait tanıtıcı bilgiler yer almaktadır. İkinci bölümde firmanın Ar-Ge ve yeniliğe yaklaşımı, yenilik süreçleri, yenilik çeşitleri hakkındaki farkındalık düzeyi ve yenilik finansmanı 
sorgulanmaktadır. Üçüncü bölümde ise firmanın başka kuruluşlarla işbirliği hakkında sorular bulunmaktadır. Dördüncü bölümde firmadan rekabet edebilirlik açısından bir durum değerlendirmesi yapması beklenmektedir. Son kısımda ise firmanın karşılaştığı zorlukların listelenmesi hedeflenmektedir. Bu çalışmada sadece üçüncü bölümde yer alan işbirliği algısını ölçmeye yönelik sorular ele alınmaktadır.

\subsection{Katılımcılar}

Çalışmanın bu kısmında saha çalışmasının yürütüldüğü firmalara ilişkin betimleyici istatistiğe yer verilmektedir. Araştırmaya katılan firmalara ilişkin tanımlayıcı bilgiler Tablo 1'de gösterilmektedir. Tablo 1 incelendiğinde, tıbbi malzeme veya cihaz üreten firmaların ağırlıklı olduğu görülmektedir (18 firma, \%72). İşletmelerin yaş ortalaması 18,12 y1l iken, standart sapması 12,54 'tür. Sahiplik yapıları incelendiğinde ise \%64'ü aile işletmesi iken, \%24'ü ortaklık yapısına sahiptir ve sadece bir işletmenin yabancı ortağı bulunmaktadır. Hedef pazarlar göz önüne alındığında, firmaların \%88 oranında yurt içini hedefledikleri, \%28'inin ise bölge içi pazara da hitap ettiği anlaşılmaktadır. Öncelikli bir sektör olan tıbbi medikal sektöründe ihracatı hedefleyen firmaların oranı ise $\% 68$ 'dir. Soru formunu yanıtlayan yetkililerin statüleri ele alındığında, \%40'ının işletme sahibi veya ortağı olduğu, \%28'inin genel müdür pozisyonunda bulunduğu ve \%20'sinin Ar-Ge veya kalite faaliyetlerinde sorumlu olduğu görülmektedir.

Tablo 1: Tanımlayıcı İstatistik

\begin{tabular}{|c|c|c|c|c|c|}
\hline $\begin{array}{c}\text { Görüşsme } \\
\text { Yapılanın } \\
\text { Ünvanı }\end{array}$ & Sayı & $\begin{array}{c}\text { Frekans } \\
(\%)\end{array}$ & Faaliyet Alanı & Sayı & $\begin{array}{c}\text { Frekans } \\
(\%)\end{array}$ \\
\hline $\begin{array}{l}\text { İssletme } \\
\text { Sahibi/Ortağı }\end{array}$ & 10 & 40 & İlaç Üretimi & 1 & 4 \\
\hline Genel Müdür & 7 & 28 & $\begin{array}{l}\text { Tibbi } \\
\text { Malzeme/Cihaz } \\
\text { Üretimi }\end{array}$ & 18 & 72 \\
\hline $\begin{array}{l}\text { Ar-Ge } \\
\text { Md./Personeli }\end{array}$ & 3 & 12 & $\begin{array}{l}\text { Medikal Sarf } \\
\text { Malzeme İmalat1 }\end{array}$ & 3 & 12 \\
\hline $\begin{array}{l}\text { Kalite } \\
\text { Sorumlusu }\end{array}$ & 2 & 8 & $\begin{array}{l}\text { Diş Protez } \\
\text { İmalat1 }\end{array}$ & 3 & 12 \\
\hline Diğer & 3 & 12 & & & \\
\hline & & & Ort. & \multicolumn{2}{|c|}{ Standart Sapma } \\
\hline \multicolumn{3}{|l|}{ İşletmenin Yaşı } & 18,12 & \multicolumn{2}{|l|}{12,54} \\
\hline Hedef Piyasa & Sayı & $\begin{array}{c}\text { Frekans } \\
(\%)\end{array}$ & Sahiplik Yapısı & Sayı & $\begin{array}{c}\text { Frekans } \\
(\%)\end{array}$ \\
\hline Bölge İçi & 7 & 28 & Aile İşletmesi & 16 & 64 \\
\hline Yurt İçi & 22 & 88 & Yerli Ortak & 6 & 24 \\
\hline Yurt Diș1 & 17 & 68 & Yabancı Ortak & 1 & 4 \\
\hline
\end{tabular}




\subsection{Bulgular}

Çalışmanın bu kısmında inovasyon ekosisteminin oluşturulması temelinde firmaların başka kuruluşlarla olan işbirliklerine ilişkin elde edilen bulgular yer almaktadır. Soru formunda işbirliğine ilişkin katılımcıların düşüncelerini tespit edebilmek için "Sizin için alanınızda/sektörünüzde işbirliği ne ifade etmektedir?" şeklinde açık uçlu bir soruya da yer verilmiştir. Bu soruya verilen yanıtları aşağıdaki şekilde sıralamak mümkündür (Tablo 2). Tabloda yer alan yanıtlardan anlaşılacağı üzere işbirliğine ilişkin farklı yaklaşımlar bulunmaktadır. Örneğin bir kısım işbirliğinin olmayacağını ifade ederken, bir kısım üretimde işbirliği olamayacağını ancak satış ve pazarlama kısmında işbirliğinin söz konusu olabileceğini vurgulamakta, bir kısım ise bilgi paylaşımı ve teknoloji transferi yapılabileceğini belirtmektedir.

Tablo 2: İşbirliğine ilişkin Sanayicilerin Algısı

\begin{tabular}{|c|l|c|}
\hline $\begin{array}{l}\text { Sıra } \\
\text { No }\end{array}$ & Yanıt & Sıklık \\
\hline 1 & İşbirliği konusunda uzlaşmazlık var & 4 \\
\hline 2 & Yeni teknolojinin anlaşılması ve know-how paylaşımı/transferi & 3 \\
\hline 3 & Ürünün satışı için yurtiçi/yurtdışı ortaklık yapmak & 3 \\
\hline 4 & $\begin{array}{l}\text { Gerek karşımızdaki firmanın gerekse kamunun imkânlarını } \\
\text { karşılıklı açması }\end{array}$ & 3 \\
\hline 5 & Ar-Ge danışmanlı̆̆ı alınması & 3 \\
\hline 6 & Personel paylaşımı yapmak & 2 \\
\hline 7 & $\begin{array}{l}\text { Birbirinin ürününü satmak ve birbirinin ürününü tamamlamak } \\
\text { (Paket ihale için ürün tamamlamak) }\end{array}$ & 1 \\
\hline 8 & Dijital sistem üreten diğer laboratuvarlarla işbirliği & 1 \\
\hline 9 & Fikir alışverişi yapmak & 1 \\
\hline 10 & Ortak akıl, pazarı daha iyi değerlendirmeye yardımcı olur & 1 \\
\hline 11 & Tedarikçiler aynı zamanda çözüm ortağıdır & 1 \\
\hline 12 & Karlılı̆̆ın artırılması için firmaların bir arada hareket etmesi & 1 \\
\hline 13 & Üretimde işbirliği olmaz & 1 \\
\hline 14 & Ana sanayi firmaları yan sanayinin gelişmesini engelliyor & 1 \\
\hline 15 & Teknik bilgi desteği & 1 \\
\hline 16 & Sektör işbirliği için uygun değil & 1 \\
\hline
\end{tabular}

Soru formunun bir kısmı yenilikçilik kaynaklarını ve işbirliği yapılma durumunu ortaya çıkarmaya yönelik "Evet/Hayır" şeklinde cevaplanabilecek 11 sorudan oluşmaktadır. Sorular ve cevaplara ilişkin frekanslar Tablo 3'te yer almaktadır. Ekosistem açısından ipucu verebileceği düşünülen cevaplar incelendiğinde, son üç yıl içerisinde başka kuruluşlarla işbirliği yaptığını belirtenlerin oranının \%44, yenilik konusunda eğitim verenlerin oranının \%56, son üç yılda üniversite ve araştırma merkezi gibi bilgi üreten kuruluşlardan hizmet alanların oranının \%60 olduğu görülmektedir. Diğer yandan, son üç yılda ürün geliştirdiğini ifade eden firmaların oranı $\% 72$, firma çalışanlarını eğitim programlarına yönlendiren firma oranı $\% 80$ ve yeniliğe özel bir harcama tahsis eden firma oranı $\% 72$ 'dir. Bulgulardan yola çıkarak firmaların yenilik yapma eğiliminde olduğu, ancak içsel 
kaynakları kullanarak yenilik yapma niyetinin ağır bastığı ve rekabet öncesi işbirliğine açık olmadıkları ifade edilebilir. Bununla birlikte beşeri sermayeye yatırım yapılmadığı da ortaya çıkmaktadır. Zira çalışanların yaratıcılığı teşvik edilmediği gibi yenilik konularında da eğitim verilmemektedir. Yine de çalışanların eğitim programına yönlendirilmesi bir yenilikçi kaynağı olarak iyi uygulamaların şirketlere transferini sağlayabilir.

Tablo 3: Yenilikçilik Kaynakları ve İşbirlikleri

\begin{tabular}{|l|l|l|}
\hline & Evet & Hayır \\
\hline $\begin{array}{l}\text { Sektörünüzde nitelikli işgücü hareketliliği olduğunu } \\
\text { düşünüyor musunuz? (firmalar arası iş değiştirmeler sıkça } \\
\text { yaşanıyor mu?) }\end{array}$ & $\% 60$ & $\% 36$ \\
\hline Son üç yılda ihracat yaptınız mı? & $\% 68$ & $\% 32$ \\
\hline $\begin{array}{l}\text { Şirketin bütçesinden yeniliğe tahsis edilen özel bir harcama } \\
\text { var mıdır? }\end{array}$ & $\% 72$ & $\% 28$ \\
\hline $\begin{array}{l}\text { Yenilikçi fikirlere katkıda bulunmak amacıyla firma içinde } \\
\text { yaratıcılık teşvik edilmekte midir? }\end{array}$ & $\% 64$ & $\% 32$ \\
\hline $\begin{array}{l}\text { Firmanız son üç yılda başka kuruluşlarla işbirliklerine gitti } \\
\text { mi? }\end{array}$ & $\% 44$ & $\% 48$ \\
\hline Firma çalışanlarınız eğitim programlarına katılıyor mu? & $\% 80$ & $\% 20$ \\
\hline Kendi ürettiğiniz Ar-Ge ürününüzü ihraç ettiniz mi? & $\% 40$ & $\% 48$ \\
\hline Yenilik konularında eğitim verilmekte midir? & $\% 56$ & $\% 44$ \\
\hline $\begin{array}{l}\text { Firmanız son üç yılda ürün geliştirme faaliyetinde bulundu } \\
\text { mu? }\end{array}$ & $\% 72$ & $\% 24$ \\
\hline $\begin{array}{l}\text { Firmanız son 3 yılda bilgi temelli hizmetler veren } \\
\text { kuruluşlardan (Üniversite, araştırma merkezleri, teknik } \\
\text { danışmanlık firmaları vb.) yararlandı mı? }\end{array}$ & $\% 60$ & $\% 36$ \\
\hline
\end{tabular}

Ayrıca katılımcıların işbirliğine ilişkin algılarını ölçebilmek için 5'li Likert ölçekli 12 soru yöneltilmiştir. Ölçeğe ilişkin istatistiki bilgiler Tablo 4'te gösterilmektedir. Ölçek "Bölge içinde firmalar bilgilerini ve becerilerini kolaylıkla paylaşırlar.", "Firmanızın kolay eriştiği bölge içi önemli bilgi kaynakları bulunmaktadır." gibi yargı ifadelerinden oluşmaktadır. Katılımcılardan "1-Hiç Katılmıyorum"dan "5-Tamamen Katıliyorum"a uzanan 5'li Likert Ölçeğinde ifadelere katılım dereceleri belirtmeleri istenmiştir. SPSS 22.0 paket programı kullanılarak analizler gerçekleştirilmiştir.

Cevapların ortalamaları incelendiğinde, genellikle ortalamanın altında kalındığı görülmektedir. Özellikle, bilgi paylaşımına ilişkin soruların en düşük ortalamalara sahip olduğu, geliştirilen işbirliklerinde mali konulara ve güvene önem verildiğini içeren ifadelerin ise en yüksek ortalamaya sahip olduğu anlaşılmaktadır. Buradan hareketle firmaların benzer işi yapan firmalarla doğrudan işbirliği geliştirme düşüncesinde olmadıkları; ancak bir üst kuruluş şemsiyesi altında bir kısım faaliyetleri birlikte yapmak üzere bir araya gelebildikleri ifade edilebilir. Özellikle bilgi ve teknoloji paylaşımı yapmaktan kaçınırken, maliyetleri azaltabilecek işbirliklerine açık oldukları belirtilebilir. 
Tablo 4: İşbirliği Ölçeği Keşfedici Faktör Analizi ve Güvenirlik Analizi

\begin{tabular}{|c|c|c|c|c|c|c|c|}
\hline İfade & $\mathbf{N}$ & Ort. & $\begin{array}{l}\text { Std. } \\
\text { Sapma }\end{array}$ & $\begin{array}{l}\text { Faktör } \\
\text { Yükü }\end{array}$ & 涉 & 离 & 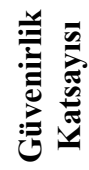 \\
\hline 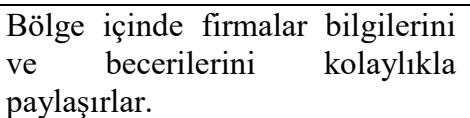 & 24 & $\begin{array}{c}1, \\
79\end{array}$ & 1,318 & ,630 & \multirow{8}{*}{ 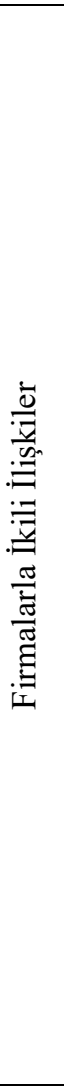 } & \multirow{8}{*}{$\% 31,61$} & \multirow{8}{*}{0,77} \\
\hline $\begin{array}{l}\text { Bölge içinde firmanızın kolay } \\
\text { eriştiği ve güncellenen ortak bir } \\
\text { bilgi havuzu oluşmuştur (açık } \\
\text { bilgi kaynakları ve firmaların } \\
\text { paylaştı̆ı kendi bilgileri) }\end{array}$ & 24 & $\begin{array}{c}1, \\
75\end{array}$ & 1,260 & ,826 & & & \\
\hline $\begin{array}{l}\text { Firmanızın kolay eriştiği bölge içi } \\
\text { önemli bilgi kaynakları } \\
\text { bulunmaktadır }\end{array}$ & 23 & $\begin{array}{l}1, \\
83\end{array}$ & 1,370 & ,667 & & & \\
\hline $\begin{array}{l}\text { Bilgi ve beceri alıs verişinde } \\
\text { bulunduğunuz firmalar ile } \\
\text { aranızda önemli teknolojik } \\
\text { benzerlikler vardır }\end{array}$ & 23 & $\begin{array}{l}2, \\
52\end{array}$ & 1,442 & ,713 & & & \\
\hline $\begin{array}{l}\text { İşbirliği yaptığınız firmalardaki } \\
\text { kaynaklar ile kendi kaynaklarınız } \\
\text { birbirlerini önemli ölçüde } \\
\text { tamamlamaktadır }\end{array}$ & 21 & $\begin{array}{r}2, \\
71\end{array}$ & 1,586 & ,622 & & & \\
\hline $\begin{array}{l}\text { İşbirliği yaptığınız firmalar ile } \\
\text { aranızda mali konularda kolaylık } \\
\text { için karşlılklı anlayıș vardır }\end{array}$ & 20 & $\begin{array}{l}3, \\
25\end{array}$ & 1,650 & ,581 & & & \\
\hline $\begin{array}{l}\text { İşbirliği yaptığınız kuruluşlar ile } \\
\text { aranızdaki ortak kültüre bağlı } \\
\text { alışkanlıklar, anlayış ve kurallar } \\
\text { karşılıklı güven kaynağıdır }\end{array}$ & 19 & $\begin{array}{l}3, \\
32\end{array}$ & 1,635 & 807 & & & \\
\hline $\begin{array}{l}\text { Ankaralılık ve/veya hemşerilik } \\
\text { bir cazibe ve güven unsurudur }\end{array}$ & 23 & $\begin{array}{r}2, \\
70 \\
\end{array}$ & 1,663 & ,774 & & & \\
\hline $\begin{array}{l}\text { Üyesi olduğunuz organizasyonlar } \\
\text { üyelerinin ortak hedefler için } \\
\text { işbirliği yapmalarına yardımcı } \\
\text { olmaktadır }\end{array}$ & 21 & $\begin{array}{c}2 \\
52\end{array}$ & 1,569 & 853 & \multirow{4}{*}{ 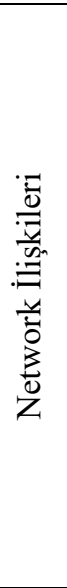 } & \multirow{4}{*}{$\% 26,29$} & \multirow{4}{*}{0,94} \\
\hline $\begin{array}{l}\text { Üyesi olduğunuz organizasyonlar } \\
\text { üyelerinin ortak kurallar içinde } \\
\text { davranmalarına } \\
\text { olmaktadır }\end{array}$ & 20 & $\begin{array}{l}2, \\
90\end{array}$ & 1,553 & ,895 & & & \\
\hline $\begin{array}{l}\text { Üyesi olduğunuz organizasyonlar } \\
\text { üyelerinin birlikte öğrenmelerine } \\
\text { yardımcı olmaktadır }\end{array}$ & 19 & $\begin{array}{c}2, \\
89\end{array}$ & 1,595 & ,969 & & & \\
\hline $\begin{array}{l}\text { İşbirliği yaptığınız kuruluşlar ile } \\
\text { olan sosyal ilişkileriniz ve } \\
\text { kurduğunuz iletişim karşılıklı } \\
\text { güven kaynağıdır }\end{array}$ & 20 & $\begin{array}{r}2, \\
90\end{array}$ & 1,714 & ,923 & & & \\
\hline \multicolumn{6}{|c|}{ Toplam } & $\% 57,90$ & 0,76 \\
\hline
\end{tabular}


Keşfedici faktör analizi (KFA) yöntemiyle ölçüm aracının geçerlik analizi yapılmıştır. KFA ile yapılan geçerlik analizi; ölçeğin madde içeriklerinin tutarlılığını belirlemek, evren için kullanılabilir ve genellenebilir yapıyı tespit edebilmek, uygun soruları bir araya getirerek faktörlere kesinlik kazandırabilmek ve ölçeği yorumlanabilir hale getirmek maksadıyla yapılmaktadır (Reise ve diğ., 2000: 287). KFA'de temel sorun alanlarından birisi örneklemin büyüklügüne ilişkindir. Literatürde örneklem büyüklüğünün ne kadar olacağına dair net bir mutabakat sağlanamadığ 1 ifade edilebilir.

Nitekim MacCallum ve arkadaşları (1999) durumsallık yaklaşımı içerisinde örneklemin büyüklüğünün her bir çalışma için farklılık göstermesi gerektiğini belirtmektedir. Yine de KFA için 100'den az katılımcının yer aldığı çalışmaların yetersiz olacağ1 yönünde bir genel kanaat bulunmaktadır (Reise ve diğ., 2000: 290). Diğer taraftan örneklem büyüklügünü ölçüm aracındaki soru sayısı ile ilişkilendiren çalışmalara da rastlanmaktadır. Örneğin; örneklem büyüklüğünün soru sayısına oranının Cattel (1978) 3-6 arası, Gorsuch (1983) 5'ten büyük ve Everitt (1975) en az 10 olması gerektiğini savunmaktadır. Ancak Barrett ve Kline (1981) 1,2 oranı ile de güçlü faktör yapısı elde edildiğini ortaya koymuştur. Benzer şekilde Arrindel ve van der Ende (1985) tarafından yapılan çalışma da 1,3 oranının yeterli olduğunu göstermiştir. $\mathrm{Bu}$ durumda bu çalışmada kullanılan örneklem büyüklüğü yeterli olmamakla birlikte örneklem büyüklügünün soru sayısına oranının 2 olması nedeniyle sinırlı da olsa yorumlama yapılabilir. Ancak çalışmada elde edilen bulgular değerlendirilirken bu durumun göz ardı edilmemesi gerekmektedir. Çalışmanın bu sınırlılığı temelinde kullanılan ölçme aracının geçerlik ve güvenirlik çalışmalarının daha büyük örneklemlerde test edilmesi önemlidir. $\mathrm{Bu}$ doğrultuda yapılan KFA sonucunda mikro seviyede firmalarla ikili ilişkiler ile makro seviyede network ilişkileri olmak üzere iki ana bileşen elde edilmiştir. Ayrıca soruların güvenirlik analizi yapılmış ve Cronbach Alfa katsayısı bileşenler için 0,77 ve 0,96 , toplamda ise 0,76 olarak tespit edilmiştir.

\section{Sonuç ve Öneriler}

Onuncu Kalkınma Planında (2014: 69) Ar-Ge ve yenilik faaliyetlerinin özel sektör odaklı olacak şekilde artırılması, elde edilecek çıktıların ticarileştirme ve markalaşma süreçlerinin hızlandırılmasıyla katma değer artışı sağlanması hedeflenmektedir. Bu hedefe uygun politikalar önceki dönemlerde olduğu gibi yürürlüğe konmuştur. 2011-2013 KOBİ Strateji ve Eylem Planı döneminde üniversite sanayi işbirliğinin geliştirilmesi maksadıyla uygulama ve araştırma merkezleri yaygınlaştırılmış, TÜBİTAK tarafından teknoloji transfer ofislerinin desteklenmesi kapsamında onlarca TTO desteklenmiştir. Diğer yandan, Üretimde Verimliliğin Artırılması Programı Eylem Planında (2015) KOBİ'lerin finansman kaynaklarına erişiminin kolaylaştırılması ve KOBI'lere $A B$ fonlarının tanıtılmasına yönelik etkinlikler düzenlenmesi yer almıştır. Bu doğrultuda KOBİ Strateji ve Eylem Planında (2015: 31) listelenen firsatlar arasında üniversite 
araştırma merkezleri ile KOBİ işbirliği faaliyetleri, AB ve diğer yurt dışı kaynaklı fonların varlığı ve kamu kaynaklı desteklerde bölgesel ve sektörel odaklanma yapılması ön plana çıkmıştır.

Bunlarla birlikte, ülkemizde bölgesel yenilik sistemlerine ilişkin özel bir yasal çerçeve bulunmadığ 1 gibi sistemlerin faaliyetlerini düzenleyen belirli bir politika alanı da mevcut değildir (Dökmen, 2012: 152). Kalkınma Planı dahil tüm stratejik belgelerin ve destekleyici uygulamaların gayesi Türkiye'nin ithalata olan bağımlılıktan kurtarılarak teknoloji ihraç edebilen bir ülke konumuna getirilmesi şeklinde özetlenebilir. Bu hedefe ulaşılabilmesi için özel kesimin, özellikle imalat sanayinin, Ar-Ge kapasitesinin geliştirilmesi ve Ar-Ge'ye olan talebin artırılması özel önem teşkil etmektedir. Bu noktada bilginin ve teknolojin transferini ve yayılımını sağlayacak arayüzlerin önemi ortaya çıkmaktadır. Zira Ar-Ge çabalarını ve inovasyon gayretlerini etkileyen temel faktörler arasında sanayisanayi işbirliği, kamu-üniversite-sanayi işbirliği ve bilgi paylaşımı ön planda yer almaktadır (Romero ve Martínez-Román, 2012: 179). Ancak üniversite sanayiden istek gelmesini beklerken sanayi de üniversitenin sanayinin sorunlarına çözüm üretmek konusunda gayret göstermediğini düşünmektedir (Ar ve diğ., 2013). Bu açıdan inovasyonun esasen işbirlikleri yönetmektir çıkarımına ulaşılabilir (Ortt ve van der Duin, 2008: 526). Yukarıda izah edilen gerekçeler doğrultusunda bölgesel inovasyon ekosistemi içerisinde firmaların yenilikçilik kaynakları ve işbirliklerine ilişkin düşüncelerini belirlemek amacıyla bu çalışma tasarlanmıştır.

Çalışmada nitel yöntemlerle elde edilen bulgularla birlikte nicel yöntemden de faydalanılmıştır. Örneğin, firmaların işbirliğine ilişkin algılarının ölçülmesi için katılımcı firmalara 5'li Likert Ölçeği ile hazırlanan 12 soru yöneltilmiştir. Keşfedici faktör analizi yapılarak soruların geçerlik analizi yapılmış ve mikro seviyede firmalar arası ikili işbirliği ile makro seviyede işbirliği ağları arasındaki işbirliği olmak üzere iki ana bileșen elde edilmiştir. Ayrıca soruların güvenirlik analizi yapılmış ve Cronbach Alfa katsayısı bileşenler için 0,77 ve 0,96, toplamda ise 0,76 olarak tespit edilmiştir. Böylelikle işbirliğini tespit etmek maksadiyla kullanılabilecek soruların geçerli ve güvenilir olduğu ifade edilebilir. Ancak örneklem sayısının artırılarak ölçeğin yapısının doğrulayıcı faktör analizi ile doğrulanması gerekmektedir.

Bulgulardan yola çıkarak firmaların yenilik yapma eğiliminde olduğu, ancak içsel kaynakları kullanarak yenilik yapma niyetinin ağır bastığı ve rekabet öncesi işbirliğine açık olmadıkları ifade edilebilir. Bununla birlikte beşeri sermayeye yatırım yapılmadığı da ortaya çıkmaktadır. Zira çalışanların yaratıcılığı teşvik edilmediği gibi yenilik konularında da eğitim verilmemektedir. Yine de çalışanların eğitim programına yönlendirilmesi bir yenilikçi kaynağı olarak iyi uygulamaların şirketlere transferini sağlayabilir. Ayrıca, firmaların benzer işi yapan firmalarla doğrudan işbirliği geliştirme düşüncesinde olmadıkları; ancak bir üst kuruluş şemsiyesi altında bir kısım faaliyetleri birlikte yapmak üzere bir araya gelebildikleri ifade edilebilir. Özellikle bilgi ve teknoloji paylaşımı yapmaktan 
kaçınırken, maliyetleri azaltabilecek işbirliklerine açık oldukları belirtilebilir. Firmaların işbirliğine ilişkin algılarını tespit etmek üzere tasarlanmış nitel ve nicel sorular birlikte değerlendirildiğinde, henüz rekabet öncesi işbirliği anlayışının firmalarda gelişmediği, özellikle bilgi paylaşımı ve tecrübe aktarımında işbirliği yapılamadığı, yenilikçilik üzerine bilgi ve bilinç eksikliği olduğu ve giderilmesi yönünde çaba gösterilmediği, özgün ürünler geliştirilemediği ve geliştirilen ürünlerin ihracata dönüştürülemediği, yetişmiş işgücünün bölge içi hareketliliğinin personele yatırım yapılmasını engellediği anlaşılmaktadır.

Bölgesel inovasyon ekosistemi içerisinde KOBİ'lerin önemi istihdamın yaklaşık \%75'ini oluşturmalarından ve 2008 krizi sonrası dönemde yaratılan katma değere katkılarının \%6 oranında artmasından kaynaklanmaktadır (OECD, 2016). Ayrıca KOBI'ler daha esnek yapıları marifetiyle daha hızl karar verebilmekte, daha pazar odaklı üretebilmekte ve yüksek riskler üstlenebilmektedir (Love ve Roper, 2015). Ancak ölçek ekonomisine sahip olunamaması ve yeterli kaynak bulunmaması KOBİ'lerin yeniliğe yaklaşımını kısıtlamaktadır (Yülek ve Daş, 2016: 181).

Kamunun öncelikli hedeflerinden birisi olarak yeniliği teşvik KOBİ politikaları açısından performansı yüksek uygulamalardan biri iken yenilikçiliğin kaynağ 1 olarak işbirliğini geliştirmede zayıf olunması politikaların yaygınlaşmasını ve sürdürülebilir olmasını engellemektedir. $\mathrm{Bu}$ nedenle bu çalışma sonucunda da ortaya çıktığı gibi oda ve borsa gibi üst kuruluşlarda oluşturulacak arayüzlerin temel hedeflerinden birisi de kültürel değişimi yönetebilmek olmalıdır. Böylelikle hem sanayinin ihtiyaçlarını net olarak tanımlayabilen, hem tanımlanan ihtiyaçlar için uygun çözümler üretilmesini temin edebilen hem de kamuda politika yapıcılar üzerinde kuvvetli lobicilik yapabilen yapılar ortaya çıkmış olacaktır. Örneğin benzer bir yapılanmanın Başkent Üniversitesi ile Anadolu Organize Sanayi Bölgesi (OSB) arasında geliştirildiği görülmektedir. İş sağlığ 1 ve güvenliği alanındaki eğitim ve danışmanlığın yanı sıra mesleki konularda eğitimler verilmesi ile birlikte Anadolu OSB bünyesindeki firmaların inovasyon ve Ar-Ge kapasitelerinin artırılması konusunda işbirliği yapılmaktadır (Fırlarer, Özgülbaş ve Varoğlu, 2015). Sonuç olarak, özel sektörde yenilikçilik ve işbirliği kapasitesinin artırılabilmesi için ihtiyaç duyulan arayüzlerin sadece üniversitelerde veya kamu sektöründe oluşturulması yerine reel kesimleri temsil eden kamu kurumu niteliğindeki meslek kuruluşları gibi üst kuruluşlarda yapılandırılmasının teşvik edilmesi gerekmektedir. Bölgesel aktörler olarak kamu hizmeti üreten oda ve borsalarda teşkil edilebilecek bu tür yapıların bölgesel yenilik sistemleri bağlamında inovasyon ekosistemlerinin oluşturulmasında etkin rol alabileceği düşünülebilir. Zira bölgesel inovasyon ekosisteminin ana unsuru olan oda ve borsalara bu görevin açıkça verilmesi ve teşvik mekanizmalar kapsamına alınması kamu-üniversite-sanayi işbirliğini artıracaktır. Böylelikle, firmaların taleplerini daha hızlı karşılayabilmek ve daha uygun yönlendirebilmek için inovasyon ekosisteminin altyapısını teşkil edecek bir yetenek havuzu da oluşturabilecektir. 
Firmalar arası ikili işbirliklerinin artırılabilmesi için sanayi-sanayi işbirliği modellerinin kurulması önemlidir. Faktör analizinde ortaya çıktığı gibi firmaların ikili işbirliğinden ziyade bir network içerisinde bir üst kuruluşun hamiliğinde bir araya gelme eğilimleri mevcuttur. $\mathrm{Bu}$ doğrultuda inovasyon ekosisteminin oluşturulması kapsamında ortak küme toplantılarına üniversitelerin davet edilmesi, oda ve borsalarda teknoloji ve bilgi günleri düzenlenerek üniversitelerin kendilerini sanayicilere tanıtma imkanı verilmesi, OSB'lerde sergiler açılarak üniversitelerde üretilen yeni ürünlerin tanıtımına katkı yapılması değer yaratacak faaliyetler olabilir. Ayrıca değişik alanlarda atölye çalışmalarının düzenlenmesi ya da çalıştaylar yapılması paydaşların bir araya gelmesi için uygun ortamlar oluşturulması açısından önem kazanmaktadır.

Diğer taraftan, başta üniversiteler olmak üzere girişimcilik ve yenilikçilik kültürünün yaygınlaştırılması gerekmektedir (Akpınar ve diğ., 2015). Bu bağlamda düzenlenen uygulamalı girişimcilik eğitimlerinde, oda ve borsalar üyelerine proje hazırlama ve uygulama, teknoloji yönetimi, inovasyon yönetimi ve bilgi yönetimi gibi konularda hizmetiçi eğitimler ve mentorlük hizmeti verebilir. Benzer şekilde kümelenmeler, OSB'ler ile Avrupa İşletmeler Ağı gibi oluşumlarda proje yönetimi konusunda bilgilendirme ve bilinçlendirme faaliyetleri yapılabilir. Girişimcilik kültürü bağlamında toplumsal farkındalık yaratmak adına ilköğretim çağındaki çocuklar dahil girişimcilik, yenilikçilik ve yöneticilik konularında bilgilendirilebilir.

Ayrıca, sektörel bazda yaygınlaştırılacak çalışma ve analizler sonucunda, firma ve sektör seviyesinde yenilikçiliğe yönelik bir yol haritası çizilebilir, üniversitesanayi işbirliği kapsamında optimal eşleştirme yapılabilir, uygun finansman modeli için yönlendirmelerde bulunulabilir ve proje hazırlama ve yönetme konusunda destek verilebilir.

Bölgesel yenilik sistemlerinin geliştirilmesi ve inovasyon ekosistemlerinin oluşturulmasında temel aktör olarak yer alması gerektiğine inanılan oda ve borsalarda oluşturulacak arayüzler ile süreçler kolaylaştırılabileceği gibi daha etkin ve etkili işleyen mekanizmalara kavuşulabilir. Meslek kuruluşu olarak oda ve borsaların itibarların yanında nüfuzlarından da yararlanmak suretiyle daha fazla imkan daha fazla ihtiyaç sahibine hızlı ve kaliteli bir şekilde ulaştırılabilir. $\mathrm{Bu}$ bağlamda arayüzlere sağlanan kamu desteklerinin oda ve borsaları kapsayacak şekilde genişletilmesi bölgesel inovasyon ekosistemlerinin oluşturulmasını hızlandirabilir.

Son olarak, inovasyon ekosistemlerinin oluşturulması ve geliştirilmesi açısından önemli görülen işbirliğine ilişsin algıyı ölçmek üzere yapılan bu çalışmanın bazı sınırlılıklarından bahsetmek mümkündür. İlk olarak geçerlik için kullanılan KFA yöntemi ile bağlantılı olarak örneklemin büyüklüğü bir sınırlılık oluşturmaktadır. Literatürde örneklem büyüklügünün ne kadar olacağına dair net bir mutabakat olmamakla birlikte 100 'den az katılımcının yer aldığ çalışmaların yetersiz olacağ yönünde bir genel kanaat bulunmaktadır. Diğer taraftan örneklem büyüklüğünün 
ölçüm aracındaki soru sayısına oranının 1,2 gibi düşük olabileceğine ilişkin çalışmalar da mevcuttur. $\mathrm{Bu}$ durumda bu çalışmada kullanılan örneklem büyüklüğü yeterli olmamakla birlikte örneklem büyüklügünün soru sayısına oranının 2 olması nedeniyle sinırlı da olsa yorumlama yapılabilir. Ancak çalışmada elde edilen bulgular değerlendirilirken bu durumun göz ard1 edilmemesi gerekmektedir. Çalışmanın bu sınırlılığı temelinde kullanılan ölçme aracının geçerlik ve güvenirlik çalışmalarının daha büyük örneklemlerde test edilmesi önemlidir. İkinci olarak çalışmanın belirli bir sektörü kapsaması da bir diğer sınırlılıktır. Üçüncü ve son olarak ise katılımcıların mevcut durumdan ziyade olması gerektiği yönünde cevap verme olasılığından bahsedilebilir.

\section{Kaynakça}

Afzal, M. N. I. (2014). An Empirical Investigation of the National Innovation System (NIS) Using Data Envelopment Analysis (DEA) and The TOBIT Model. International Review of Applied Economics, 28(4), 507-523.

Ar, İ. M., Alemdar, Ö. F., Katırcı, B. ve Çelik, A. (2013). Üniversite-Sanayi İşbirliği Çerçevesinde Trabzon'daki Organize Sanayi Bölgeleri Üzerine Bir Araştırma. 4. Ulusal Verimlilik Kongresi, Ankara, 10-12 Aralık 2013.

Arrindell, W. A. ve van der Ende. J. (1985). An Empirical Test of the Utility of the Observations-to-Variables Ratio in Factor and Components Analysis. Applied Psychological Measurement, 9, 165-178.

Barrett, P. T. ve Kline. P. (1981). The Observation to Variable Ratio in Factor Analysis. Personality Study in Group Behavior, I, 23-33.

Cattell, R. B. (1978). The Scientific Use of Factor Analysis. New York: Plenum.

Cornell University, INSEAD ve WIPO (2018). The Global Innovation Index 2018: Energizing the World with Innovation. Fontainebleau, Ithaca, and Geneva.

DPT (2010). Üniversite ve Kamu Kurumları Araştırma Merkezleri, Ankara. Erişim Adresi http://www3.kalkinma.gov.tr/DocObjects/Download/15042/ Universite_ve_Kamu_Kurumlari_Arastirma_Merkezleri.pdf

Dökmen, G. (2012). Bölgesel Yenilik Sistemlerinde Devletin Rolü: Düzey 2 Bölgelerine İlişkin Ampirik Bir Analiz. Yönetim ve Ekonomi, 19(2), 143-163.

Elçi, Ş. ve Karataylı, İ. (2008). Inovasyon Rehberi: Kârlılık ve Rekabetin Elkitabı. Technopolis Group, Ankara. Erişim Adresi http://www.ansiad.org.tr/upload/2017020813054488-inovasyon.pdf

Ersöz, F. (2009a). Savunma Yeteneklerinin Geliştirilmesinde Bilgi\&Teknoloji, Ar-Ge ve İnovasyon'un Rolü ile İnovasyon Göstergelerine göre Türkiye'nin Yeri. TÜBAV Bilim Dergisi, 2(3), 364-371. 
Ersöz, F. (2009b). Avrupa İnovasyon Göstergeleri (EIS) Işı̆̆ında Türkiye'nin Konumu. ITÜ Dergisi/B: Sosyal Bilimler, 6(1), 2009b, 3-16.

Etzkowitz, H. ve Leydesdorff, L. (2000). The Dynamics of Innovation from National Systems and "Mode 2" to A Triple Helix Of University-IndustryGovernment Relations. Research Policy, 29(2), 109-123.

Everitt, B. S. (1975). Multivariate Analysis: The Need for Data, and Other Problems. British Journal of Psychiatry, 126, 237-240.

Fırlarer, A., Özgülbaş, N. ve Varoğlu, A. K. (2015). Üniversite - Organize Sanayi Bölgesi İşbirliği: Başkent Üniversitesi - Anadolu Organize Sanayi Bölgesi Modeli. ÜSIMP 2015 - Üniversite-Sanayi İşbirliği 8. Ulusal Kongresi, Konya, 9-10 Haziran 2015.

Gorsuch, R. L. (1983). Factor Analysis (2. Bask1). Hillsdale, NJ: Erlbaum.

Göker, A. (2012). Yine Üniversite-Sanayi İşbirliği (V). Cumhuriyet Bilim Teknik Dergisi.

Hancioğlu, Y. ve Atay, Ö. Dünya İnovasyon Lideri İsviçre ve Türkiye Ulusal İnovasyon Sistemlerinin Karşılaştırmalı Bir Değerlendirmesi. Dokuz Eylül Üniversitesi Işletme Fakültesi Dergisi, 19(1), 51-88.

Innovation Union Scoreboard (2018). Erişim adresi https://ec.europa.eu/growth/industry/innovation/facts-figures/scoreboards_en

Keizer, J., Dijstra, L. ve Halman, J. I. M. (2002), Explaining Innovative Efforts of SMEs. An Exploratory Survey among SMEs in the Mechanical and Electrical Engineering Sector in The Netherlands, Technovation, 22, 1-13.

Kiper, M. (2010). Dünyada ve Türkiye'de Üniversite-Sanayi Işbirliği: Ve Bu Kapsamda Üniversite Sanayi Ortak Araştırma Merkezleri Programı (ÜSAMP). Ankara: TTGV.

KOBİ Strateji ve Eylem Planı (2015). T.C. Resmi Gazete (29466, 05 Eylül 2015).

Love, J. H. ve Roper, S. (2015). SME Innovation, Exporting and Growth: A Review of Existing Evidence. International Small Business Journal, 33(1), 2848.

MacCallum, R. C., Widaman, K. F., Zhang, S. ve Hong, S. (1999). Sample Size in Factor Analysis. Psychological Methods, 4, 84-99.

OECD (2016). Turkey Policy Brief, July, OECD Better Policies Series, OECD. Erişim Adresi https://www.oecd.org/policy-briefs/turkey-removingadministrative-and-regulatory-barriers-to-competition.pdf

Ortt, J. R. ve van der Duin, P. A. (2008). The Evolution of Innovation Management towards Contextual Innovation. European Journal of Innovation Management, 11(4), 522-538. 
Özbek, H. ve Atik, H. (2013). İnovasyon Göstergeleri Bakımından Türkiye'nin Avrupa Birliği Ülkeleri Arasındaki Yeri: İstatistiksel Bir Analiz. Erciyes Üniversitesi İktisadi ve İdari Bilimler Fakültesi Dergisi, 42, 193-210.

Reise, S. P., Waller, N. G. ve Comrey, A. L. (2000). Factor Analysis and Scale Revision. Psychological Assessment, 12(3), 287-297.

Romero, I. ve Martínez-Román, J. A. (2012), Self-Employment and Innovation Exploring the Determinants of Innovative Behavior in Small Businesses, Research Policy, 41, 178-189.

Skiltere, D. ve Jesilevska, J. (2013). Innovative Performance and Innovation System of Latvia. Regional Formation and Development Studies, 2(10), 211218.

Solow, R.M. (1987). Growth Theory and After. 8 Aralık 1987 Nobel Ödülü konuşması. Erişim Adresi https://www.nobelprize.org/prizes/economics /1987/solow/lecture/

Soylu, A. (2011). “AB 2020" ve "Vizyon 2023" Stratejilerinde İnovasyon Hedeflerinin Karşılaştırılması. Süleyman Demirel Üniversitesi Sosyal Bilimler Enstitüsü Dergisi, (14), 105-122.

Tuncel, C. O. (2014). Orta Gelir Tuzağı ve İnovasyon Politikaları: Doğu Asya Deneyimi ve Türkiye İçin Dersler. Maliye Dergisi, 167, 40-70.

Üretimde Verimliliğin Artırılması Programı Eylem Planı (2015). Erişim Adresi http://odop.kalkinma.gov.tr/dokumanlar/1uretimde_verimliligin_arttirilmasi_e ylem_plani.pdf

Yardımcı, A. ve Müftüoğlu, E. B. (2014). Üniversite Sanayi İşbirliğinde Sanayi Kesiminin Beklentileri ve Sorunları. Ankara: TOBB Yayınları.

Yülek, M. ve Daş, G. S. (2016). KOBİ'lerin Yenilikçilik Kapasitelerini Geliştirecek Desteklerin Tasarımına Yönelik Kavramsal Bir Model Önerisi: Yenilikçilik Profillerine Dayalı Bir Yaklaşım. Ege Akademik Bakış, 16(3), 161-176.

Onuncu Kalkınma Planı (2014). T.C. Resmi Gazete (28699 (Mükerrer), 06 Temmuz 2013). 